\title{
Women in Poverty: A New Global Underclass
}

\author{
Mayra Buvinic
}


Mayra Buvinic is Chief of the Social Development Division of the Sustainable Development Department.

This article first appeared in the Fall 1997 edition of Foreign Policy, and is reprinted with permission. The Spanish version of this article appeared separately in the Venezuelan edition of Foreign Policy in January 1998 and contains some differences from the English version. 


\section{Women in Poverty}

To understand the plight of poor women around the world, consider the stories of Ade, Runa, and Reina. On the outskirts of Ibadan, Nigeria, Ade cultivates a small, sparsely planted plot with a baby on her back and other visibly undernourished children nearby. Her efforts to grow an improved soybean variety, which could have fortified her children's diet, failed because she lacked the extra time to tend the new crop, did not have a spouse who could help her, and could not afford hired labor. Runa, a young woman with boundless energy, piercing eyes, and a warm smile, founded and runs the SelfEmployed Women's Association in the Indian city of Lucknow, one of the country's most disadvantaged regions. Until a year ago, she had been unable to obtain credit from local banks for her impressively wellorganized business, which now employs about 5,000 women homeworkers who sell chikan embroidery in national and international markets. Reina is a former guerrilla fighter in El Salvador who is being taught how to bake bread under a post-civil war reconstruction program. But as she says, "The only thing I have is this training and I don't want to be just a baker. I have other dreams for my life."

A farmer, an entrepreneur, and a former guerrilla - the working lives of these three women have little in common, except that they, along with most women worldwide, face similar obstacles to increasing their economic power: no "slack" time to invest in additional work that could bring in needed income; lack of access to commercial credit; and training in traditionally female-and mostly low-wage — skills. These obstacles differentiate the work experiences of men and women, exacerbate women's poverty, and sustain a vicious cycle of impoverishment from one generation to the next.

They also help to account for a disturbing global trend: the feminization of poverty. When the yardstick used to measure the degree of people's poverty is their level of well-being, women are traditionally found to be more impoverished than men. But poverty is more commonly defined according to income, and today, although the gap between the two sexes is decreasing in terms of wellbeing, it is increasing in terms of income. The evidence is imperfect, but current trends suggest that women account for a growing proportion of those people who are considered poor on the basis of income, not only in industrial countries such as the United States, but also in the developing world.

\section{POOR WOMEN, POOR WORLD}

This feminization of poverty should be considered a legitimate foreign policy concern. Because women are increasingly economic actors and heads of households as well as mothers, their poverty slows global economic growth. Moreover, in poor countries, their disadvantage feeds a destructive spiral of poverty, population growth, and environmental degradation. In a world of blurring borders, women's poverty creates enclaves of want in the midst of wealth and puts rising pressures on the developed world, whether by fueling costly humanitarian crises or by unleashing-for the first time- waves of females who 
migrate without spouses to seek work in richer countries.

The United States and other industrial countries have much to gain by reducing the impoverishment of women in developing countries. Not only can there be no substantial easing of world poverty until the international community focuses on female well-being as a goal and widens women's economic opportunities, but in this age of shrinking foreign aid budgets, investing in women offers policy-makers the highest economic and social returns at the lowest cost.

Poverty has many dimensions and is difficult to measure. Calculated in dollars and cents, it is inadequacy of income. But measured in terms of the human condition, it is inadequacy of health and nutrition, education, and other components of wellbeing, including leisure time.

There is broad evidence that women in developing countries seem to bear the brunt of this latter type of "capability-based" poverty. In 1996, the United Nations Development Programme (UNDP) introduced a new index in its annual Human Development Report that reflects the percentage of people who lack three basic, or minimally essential, capabilities: to be well nourished and healthy (measured by the proportion of children under five who are underweight); to reproduce healthily (assessed by the proportion of births unattended by trained health personnel); and to be educated (represented by rates of illiteracy). This index primarily gauges women's deprivation since two of the three measures pick up disadvantages that are specific to women. Calculations show that 37 percent of the population in developing countries, or 1.6 billion people, lack these three essentials of well-being, while only 21 percent of them, or 900 million people, are "income poor," with incomes below the poverty line as defined by the World Bank. Most of the "extra" 700 million poor are women.

Statistics that show women lagging behind men in terms of well-being support the idea that women bear more than their fair share of capability-based poverty.

Global literacy statistics show that in 1990 there were only 74 literate women for every 100 literate men. Schooling statistics reveal a similar trend. Worldwide, 77 million girls of primary school age (6-11 years old) are out of school, compared with 52 million boys-a gap that becomes even larger when girls' higher overall dropout rates, absenteeism, and repetition levels are taken into account.

Contrary to the biological advantage in survival that females have over males at all ages, men outnumber women in some regions, especially in South Asia, which is home to about one-half of the world's poor. Using vital statistics on the actual ratio of women to men in a society and contrasting them with those figures on the ratio expected if there were no female disadvantage in survival, economist and philosopher Amartya Sen of Harvard University has estimated that more than 100 million females are "missing" globally-a stark figure that he attributes to the comparative neglect of female health and nutrition, especially, but not exclusively, during childhood.

Time is perhaps the one resource that the poor have available to them, and study after study shows that in poor families males have more leisure time than their female kin. To take care of their families, women farmers wake up before dawn in Honduras to grind the corn 


\begin{tabular}{|c|c|c|c|c|c|c|c|c|}
\hline \multicolumn{9}{|c|}{ Four Key Indicators of Women's Quality of Life } \\
\hline \multirow[b]{2}{*}{ Region } & \multicolumn{2}{|c|}{$\begin{array}{c}\text { Life Expectancy } \\
\text { (years) }\end{array}$} & \multicolumn{2}{|c|}{$\begin{array}{l}\text { Fertility }^{\mathrm{b}} \\
\text { (births per } \\
\text { woman) }\end{array}$} & \multicolumn{2}{|c|}{$\begin{array}{l}\text { Girls Enrolled in } \\
\text { Primary School }^{\mathrm{c}} \\
\text { (percent) }\end{array}$} & \multicolumn{2}{|c|}{$\begin{array}{c}\text { Women Aged } \\
\text { 15-44 Using Modern } \\
\text { Contraception } \\
\text { (percent) }\end{array}$} \\
\hline & 1970 & 1990 & 1970 & 1990 & 1970 & 1990 & 1970 & 1990 \\
\hline Arab States & 57 & 65 & 6.1 & 4.7 & 46 & 92 & 29 & 52 \\
\hline East Asia & 65 & 72 & 4.4 & 2.2 & $95^{\mathrm{d}}$ & $113^{\mathrm{d}}$ & 69 & 81 \\
\hline $\begin{array}{l}\text { Latin America } \\
\text { and the } \\
\text { Caribbean }\end{array}$ & 64 & 70 & 5.0 & 3.2 & 89 & 103 & 39 & 52 \\
\hline OECD & 75 & 79 & 2.1 & 1.8 & 104 & 102 & 68 & 73 \\
\hline South Asia & 49 & 57 & 5.8 & 4.5 & 53 & 75 & 30 & 39 \\
\hline $\begin{array}{l}\text { Southeast Asia } \\
\text { and Oceania }\end{array}$ & 54 & 63 & 5.3 & 3.6 & - & - & 33 & 51 \\
\hline $\begin{array}{l}\text { Sub-Saharan } \\
\text { Africa }\end{array}$ & 47 & 52 & 6.7 & 6.5 & 36 & 67 & 14 & 19 \\
\hline
\end{tabular}

${ }^{\text {a }}$ Regional average weighted by each country's total female population.

${ }^{\mathrm{b}}$ Regional average weighted by each country's total female population aged 15-44.

${ }^{\mathrm{c}}$ Girls aged 6-11. The gross enrollment ratio may exceed 100 if the actual age distribution of pupils goes outside the official school ages, e.g., because of early age at enrollment, repetition of grades, etc. Data for 1970 from UNESCO World Education Report 1991 (Paris: UNESCO, 1991); 1986-92 data from UNICEF 1995 State of the World's Children (New York: Oxford University Press, 1995); all other data from WISTAT Database, version 3, United Nations, New York.

${ }^{\mathrm{d}}$ Includes figures for East Asia, Southeast Asia, and Oceania.

Source: International Center for Research on Women, Washington, D.C., 1995.

for tortillas, in Nigeria to process cassava, and in Nepal to fetch water and firewood. Put simply, women in poor households work more hours than men, and the poorer the household, the longer women work.

While statistics on female reproductive health tell little about gender differences in poverty levels, they help to reveal women's disadvantage in poor countries, where high fertility and maternal mortality rates are the norm. About one-half million women die every year from complications related to pregnancy and delivery, the majority in poor countries. In some countries in sub-Saharan Africa, approximately one woman in 50 dies during childbirth-a grim contrast to Scandinavia where the rate is one per 20,000. At a total fertility rate of seven or more children per woman, the odds of such a woman surviving her reproductive years is one in six. As economist Partha Dasgupta of Cambridge University observes, for these women producing children is like playing Russian roulette. The good news is that two decades ago, the proportion of women lacking the basics of well-being would have been much higher. Between 1970 and 1990, the life expectancy at birth of the average woman in the developing world rose by as much as five to nine years. She had substantially more schooling than she had in 1970 , especially in the poorest countries where the school-age population of girls almost doubled. She also had greater access to modern contraception. As a result, global fertility rates fell by 40 percent. Unfortunately, international statistics on women are not disaggregated by levels of income, and it is likely that the quality of life 
of better-off women improved more than that of poor ones. Still, there is evidence of substantial gains in well-being, even for women in the most impoverished countries.

The bad news, however, is that while poor women have made gains in overall wellbeing, they are falling behind in terms of income. Measuring household income or consumption is intrinsically difficult; even more so is apportioning this household income by gender, or separating women's income from men's. One way to gauge gender differences in poverty levels is to compare the situation of female-headed households with that of male-headed ones in developing countries. Looking at femaleheaded households also makes sense because in industrial countries such as the United States, where information on individuals and households is more reliable, the feminization of poverty has been closely linked with the rise in poor households headed by women.

Using information on female-headed households, the International Fund for Agricultural Development estimated the extent of rural poverty in 41 developing countries, which together account for 84 percent of the total rural developing country population. They found that between 196570 and 1988, the number of women in rural communities living below the poverty line rose more than the number of rural men living below the poverty line-increasing by 47 percent for women versus 30 percent for men. While in 1965-70 women made up 57 percent of the rural poor, by 1988 they accounted for 60 percent.

\begin{tabular}{|c|c|c|c|}
\hline \multicolumn{4}{|c|}{ Total Number of Rural F'eople Living Below Poverty Line by Sex ${ }^{1}$} \\
\hline & $1965-70$ & 1988 & Percent Change \\
\hline Women & $383,673,000$ & $564,000,000$ & 47.0 \\
\hline Men & $288,832,000$ & $375,481,000$ & 30.0 \\
\hline Total & $672,505,000$ & $939,481,000$ & 39.7 \\
\hline
\end{tabular}

${ }^{1}$ Calculated on the basis of 41 countries with data accounting for 84 percent of the total rural population of 114 developing countries.

Source: I. Jaziry, M. Alamgir, and T. Panuccio, The State of World Rural Poverty: An Inquiry into Its Causes and Consequences (New York: New York University Press, 1992).

\begin{tabular}{|l|c|c|c|c|}
\hline \multicolumn{5}{|c|}{ The Feminization of the Agricultural Work Force (1980-94) } \\
\hline \multirow{2}{*}{ Region } & \multicolumn{2}{|c|}{1980} & \multicolumn{2}{c|}{1994} \\
\cline { 2 - 5 } & Millions & Percentage & Millions & Percentage \\
\hline Africa & 31.5 & 43.7 & 43.6 & 44.4 \\
\hline Asia & 267.7 & 41.5 & 348.5 & 43.4 \\
\hline $\begin{array}{l}\text { Latin America } \\
\text { and the Caribbean }\end{array}$ & 3.8 & 13.3 & 4.4 & 18.0 \\
\hline Eastern Europe & 6.9 & 51.3 & 5.4 & 46.9 \\
\hline OECD & 15.1 & 37.5 & 11.8 & 34.9 \\
\hline Developing Countries & 309.9 & 41.6 & 402.0 & 43.0 \\
\hline
\end{tabular}

Source: Rekha Mehra and Sarah Gammage, "Trends, Countertrends and Gaps in Women's Employment," unpublished paper, International Center for Research on Women, Washington, D.C. (from WISTAT United Nations Database, 1995). 
Female-headed households used to be the exception in developing societies, but no longer. In recent decades, the percentage of households headed by women has risen. Women everywhere are shouldering households' economic burdens. They are farmers in southern Botswana and Uttar Pradesh, India, left behind to mind farm and family by migrant husbands who sometimes do, and sometimes do not, send remittances back home. They are abandoned wives and young widows in Bangladesh and Egypt; unwed mothers in Latin American and subSaharan African cities; and refugee women with children throughout the world. Data compiled by the Population Council show a rise in female-headed households in 18 out of 26 censuses and surveys reviewed globally. Tabulations by the U.N. Economic Commission for Latin America and the Caribbean (ECLAC) find this trend in 8 out of 13 countries in the region.

Another new phenomenon in some countries is households maintained by wives. Two Argentine researchers, Rosa Geldstein and Nena Delpino, report that the number of households maintained by women in Buenos Aires rose from 19 percent in 1980 to 27 percent in 1992-one in every 3.7 households. Almost one-half of these female heads of household were wives who became main earners. Wife-householders were more prevalent in the middle-income groups, and their earnings helped families through economic downturns. Unpartnered females with children were more typical of lowincome households. Where wives were the main earners and had small children, one-half of the households were poor; this figure rose to two-thirds for households with unpartnered female heads (while for all Buenos Aires households the figure was 40 percent).

The available evidence suggests that most female-headed families, especially those with younger children, are overrepresented among the poor. Data from ECLAC show that they are more numerous in the lowest income (indigent) category in 9 out of 13 countries. The International Center for Research on Women reviewed 61 headship studies conducted in developing countries over the last decade and in 53 of them found greater poverty in female-headed families. And if anything, the deficiencies in how we measure poverty (including the fact that leisure time is not computed as a household resource) suggest that the poverty of female-headed households is underreported.

A main reason for the greater poverty of these families is the lower earnings of the women heading them. Trends such as lower fertility and increased female schooling, combined with the economic downturns that many countries suffered during the 1980s and 1990s, have led to more women working in both low-paid market activities and in nonmarket production. In developing countries, we have seen a feminization of agricultural work, a sector characterized by low earnings. Women seek market work to "weather" the effects of economic and environmental crises. They also tend to spend more time participating in unpaid activities such as community kitchens, and in providing primary health care to compensate for reduced government services.

\section{Planting Seeds of Hope}

Despite the important role that women in developing countries play in agriculture, they have often been denied the attention and assistance given to their male colleagues. For example, predominantly male 
agricultural extension agents (the primary purveyors of everything from fertilizer to new farming techniques) have generally failed to seek out or assist female farmers.

To help bridge this gap in Zambia, where 75 percent of the labor force engages in agricultural work, the United Nations Food and Agricultural Organization began an effort in 1983 to help organize poor rural women and men into small groups devoted to farming, trading, and craftsmaking. The People's Participation Program (PPP) aims to improve living conditions by increasing access to rural services, encouraging group savings, and fostering self-reliance, with a special emphasis on the needs of women. Locally recruited group promoters-all women-help the groups to grow and serve as links to other groups and external agencies.

By 1995, the program had created 230 small groups in Zambia's Western Province. Of the 2,550 people directly affected, 73 percent were women, 32 percent of whom were heads of households. As a result of the PPP, access to agricultural extension services increased for 67 percent of the groups engaged in farming. The increase was particularly large for women, many of whom had never before been visited by an extension agent. Research showed that from 1983 to 1994, the average land under cultivation in three districts participating in the program had increased between 30 and 90 percent. A group-based savings program also began to show results, leading to the establishment of an informal village banking system that mainly serves female clients. For many women, the program also offered the first chance to be involved in making decisions, in some cases deepening their involvement in village affairs.

Today, the Zambian PPP encompasses 386 groups serving 4,402 members (indirectly reaching about 22,500 household members), and similar PPPs reach out to poor rural men and women in other parts of Africa, Asia, and Central America. One sign of the program's success is the widespread adoption of its small-group approach in Zambia and other aid groups. More revealing, perhaps, is that 55 percent of the Zambian PPP members are now men.

Research on the economics of poor households and families has shown that increased family burdens, including declining household income or additional children, tend to change women's and children's-but not men's - allocation of time between work and leisure. That women respond to increased external demands on the family by sacrificing more of their leisure time is a gender feature in poor families. Poor women can be caught in a vicious cycle of deprivation: Unable to cope with too much work, they hand over child-care responsibilities to older daughters, who then must drop out of school. Thus, deprivation carries from one generation of women to the next, leading to the feminization of income poverty.

It is widely known that women's access to paid employment has increased significantly in recent decades, as has their social equality in many countries. Why, then, are more and more women finding themselves in poverty? Mahbub ul Haq, principal coordinator of the 1995 UNDP Human Development Report, which carried a special section on women, summarized women's achievements in the last decades as "a story of expanding capabilities and limited opportunities." Social and economic progress, including the contributions of development assistance and the international women's movement, have improved the well-being of women and better equipped them for the world of paid work and public life. Women have left their homes and their farms. A few have broken barriers and risen to the top, but most have encountered limited opportunities.

The majority of women obtain low-wage work because of persistent sexual discrimination in terms of employment and wages. In Honduras, for example, coffee and tobacco farmers prefer to hire girls and 
women as laborers because they are willing to accept lower wages and are more reliable workers. Especially in poor countries, female labor is primarily sought for low-paid positions in services, agriculture, small-scale commerce, and in the growing, unregulated manufacturing and agribusiness industries, which pay their workers individual rather than family wages, offer seasonal or parttime employment, and carry few or no benefits. Hence, this explains the seemingly contradictory trends of women's increased economic participation alongside their growing impoverishment.

\section{BREAKING THE VICIOUS CYCLE}

The vicious cycle of poverty that unfolds when women work more and earn less and children, as a result, get less food and maternal time, is both commonplace and hard to break. But recent studies have also made clear that while households headed or maintained by women may lack resources, they are generally more "resourceful" than their male counterparts. In Brazil, for instance, economist Duncan Thomas has found that income in the hands of mothers has an effect on child health that is almost 20 times greater than income that is controlled by the father. Similar results have been reported in Chile, Guatemala, Kenya, and Malawi. The key appears to be that in households where women control resources, they prefer (whether for reasons of nature or nurture) to invest scarce resources in child well-being. In Jamaica, for instance, studies have found that female-headed households spend more on food and other family-oriented goods than male-headed households.
These differences in the way that men and women prefer to spend scarce resources in poor households suggest that the income that poor women earn can yield higher health or social benefits than that earned by men. They are a strong argument for the desirability of expanding poor women's economic opportunities - precisely the area where there has been little, if any, advancement in recent decades. In short, the question before individual nations and the international community at large is not why they should invest more in women, but how. Nations need to take measures that reinforce the virtuous cycle between poor women's and children's well-being. They also need to avoid actions that aggravate the obstacles that women and children already face.

A good place to start would be avoiding the unintended consequences of social and economic policies that can increase women's work burdens-such as reducing those public services that cushion the impact of negative economic shocks (see Ricardo Hausmann's article "Will Volatility Kill Market Democracy?" on pp. 54-67 in the Winter 1997 issue of Foreign Policy). Taking such measures without providing complementary policies that adequately "protect" poor women in their multiple roles as producers and reproducers is likely to set in motion, or intensify, the poverty cycle. Enlightened approaches such as providing women with access to reliable credit and savings can have multiplier effects that raise poor women's productivity in the home, as well as productivity and earnings in the market.

With that in mind, policymakers should also stop promoting well-meaning programs that 


\begin{tabular}{|ll|}
\hline Costs and Benefits of One Additional Year of Schooling For 1,000 Women in Pakistan (Estimated) \\
\hline Schooling: & $\begin{array}{c}\text { Costs } \\
\text { Cost for } 1,000 \text { women }=\$ 30,000 \\
\text { Benefits }\end{array}$ \\
Female Earnings: & Increase in wages $=20 \%$ \\
Child Mortality: & Child deaths averted $=60$ \\
& Alternative health intervention to save 60 lives $=\$ 48,000$ \\
Fertility: & Total births averted $=500$ \\
& Alternative family planning costs per 500 births averted $=\$ 33,000$ \\
Maternal Mortality: & Total maternal deaths averted $=3$ \\
& Alternative costs per 3 averted maternal deaths $=\$ 7,500$ \\
\hline
\end{tabular}

Source: Lawrence H. Summers, Investing in All the People, World Bank Policy Research working paper 905. (Washington, D.C.: The World Bank, May 1992).

ignore women's traditional productive roles, the economic value of their time, and their domestic time constraints. One project, for example, established a cooperative for rural women in western Kenya that produced potholders for sale in Nairobi at a price lower than the cost of the banana fiber that was used to make them.

There are several other specific areas of national and international policy where changes and improvements could yield great dividends for poor women and for the developing world in general. Governments should take the following measures:

Expand substantially the access of poor women to family-planning and reproductive health services. Many successful reproductive health programs offer women a package of health services for themselves-and sometimes their children-bundled into one visit, in one location, which saves them both time and transportation costs. Boosting women's capacities to generate income will also increase their access to higher quality health services that may be purchased through private providers.

Adopt education reform agendas designed to increase the quantity and quality of, first primary, and then secondary, schooling for girls. With the support of international agencies, innovative efforts to increase girls' access to schools are under way in Bangladesh, Pakistan, and other countries. These include giving scholarships and engaging families and communities in the task of getting and keeping girls enrolled. As World Bank vice president Mieko Nishimizu has said, "If you educate a boy you educate a human being. If you educate a girl, you educate generations."

Create incentives for the private sector

to expand women's access to agencies that offer credit and savings services. Microfinance operations, like the well-known Grameen Bank in Bangladesh, have succeeded in providing access to reliable credit and savings services to more than 3 million female borrowers in developing countries, but such operations still reach only about 5 percent of those in need of their services. They also provide benefits in other areas. One female microcredit client in Bangladesh, for example, mentioned that the profits from her expanded business had enabled her to buy a rickshaw for her unemployed husband to use as a 
taxi. As a result, she mentioned in passing, he had stopped beating her.

Increase rural women's access to agricultural extension services by modifying existing ones or by establishing separate services for them. Currently, women farmers receive fewer farm extension services than men. In western Kenya, the lack of these services accounted for about 30 percent of the productivity loss in food crops grown by women.

Expand women's access to productive infrastructure, especially in rural areas. This requires shifting government investment priorities to favor rural roads, improving women's access to water and electricity, and designing infrastructure that will support rural women as well as men.

Adopt labor-intensive "pro-poor" economic growth policies that expand employment opportunities. Invest in upgrading women's skills in both traditional and nontraditional occupations that can compete in national as well as export markets.

Overhaul social security systems as a complement to pro-poor growth policies, establishing gender-friendly regulatory frameworks for industrial and agricultural growth, and legislating childcare options.

Target agricultural policies at impoverished farmers and give women farmers access to land titles. Financial policies should promote the growth of small enterprises and foster entrepreneurship among women.
Change statistical collection systemsthat which is not counted is not valued. Much of the poor's productive work worldwide takes place in the informal sector, in homebased production, petty trading, and small-holder agriculture. Such work is still mostly invisible in labor force and employment statistics. Globalization, export promotion, and deregulation have all dramatically changed the nature of labor markets, and women's participation in them, while employment statistics have lagged behind. If women are not counted as working in productive activities, and employment trends are not disaggregated by gender, it will be hard to justify the implementation of public policies designed to increase women's productivity and wages.

Women's issues are becoming more visible in U.S. foreign policy. But although Secretary of State Madeleine K. Albright has legitimized a concern for women in foreign policy, she has done so primarily within a human rights framework. A growing body of statistical evidence shows that for developing countries what makes sense in terms of human rights also makes sense in terms of economics. If not out of altruism, then for reasons of bald self-interest, developed countries should work to expand the economic opportunities of poor women. Once upon a time, women like Reina, the former guerrilla fighter in El Salvador, only migrated to follow or find a husband. This is no longer the case. It is likely that Reina, with few opportunities in her own country, will sooner or later join the rising number of female migrants who leave families and children behind to seek better paying work in the United States and other industrial countries. Wisely spent foreign aid can give Reina the chance to realize her dreams in her own country. I have not met Reina but I have met Runa and Ade, and I am convinced that 
they represent some of the wisest and safest

today.

investments available in the developing world

\section{Show Me the Money}

Poor, often illiterate women without any collateral do not exactly rank high among banks' traditional list of preferred customers. However, microfinance institutions-which offer small loans usually secured by peer pressure rather than property-are rapidly emerging as an alternative to help women break the cycle of poverty.

One of the forerunners in the microcredit industry is Bolivia's Banco Solidario S.A., better known as BancoSol. In 1992, after operating for several years as a nonprofit joint venture between members of the business community and Acción International, a Boston-based nongovernmental organization, BancoSol became the first private commercial bank dedicated to microlending. Now it serves over 76,000 borrowers - 70 percent of whom are women-through 33 branch offices, making it the largest Bolivian bank in terms of number of borrowers. In 1996, the bank loaned slightly more than $\$ 100$ million.

To be eligible for credit, would-be borrowers must form "solidarity groups" of four to seven entrepreneurs. Each group member is responsible for the loan, a division of responsibility that helps to guarantee it will be repaid. The average loan is $\$ 600$, although first loans are typically much smaller, averaging around $\$ 150$. After groups demonstrate their ability to be responsible borrowers by paying back their initial loans, they become eligible for more credit. At the end of 1996, default rates were only 2.6 percent-much lower than in the financial system as a whole.

BancoSol's typical clients are urban artisans and merchants for whom even a small line of credit can mean the difference between self-sufficiency and brutal poverty. As the Wall Street Journal recently reported, one Bolivian woman, Gloria Quintanilla, went from selling clothes on the street to owning her own shop, mainly due to the loans she received from BancoSol. Teresa Montano used a \$125 loan to transform her one-woman bakery into a business that employs 14 people, according to the Minneapolis Star Tribune. Microlending programs around the world have spawned similar successes, from Uganda and Indonesia to Bangladesh, and the Philippines. Indeed, microcredit lending is growing at an annual rate of 30 percent and, by the end of 1997 , it is expected to total as much as $\$ 12$ billion.

\section{WANT TO KNOW MORE?}

The second edition of Women... A World Survey (Washington, D.C.: World Priorities, 1995) provides a concise and readable analysis of progress in the situation of women in the past decades and the constraints they face. The 1995 UNDP Human Development Report (New York: Oxford University Press, 1995) presents a more detailed examination of the same issues. Both sources will give readers a good grasp of the similarities women share as well as the profound differences that exist between women in rich and poor countries. Readers interested in the issue of women and families should consult Families in Focus: New Perspectives on Mothers, Fathers, and Children, by Judith Bruce, Cynthia Lloyd, and Ann Leonard (New York: Population Council, 1995).

Gender, Poverty and Employment: Turning Capabilities into Entitlements (Geneva: International Labour Office, 1995), portrays the situation of poor women and evaluates possible actions to combat their poverty. For insightful, empirically grounded analyses on the extreme discrimination some women suffer and the vicious cycles of gender-based poverty, see Amartya K. Sen's article "More than 100 Million Women are Missing" (New York Review of Books, December 20, 1990) and Partha S. Dasgupta's "Population, Poverty and the Local Environment" (Scientific American, February 1995). Seeds 2: Supporting Women's Work around the World, Ann Leonard, ed. (New York: The 
Feminist Press, 1995), describes what working women around the world do to escape poverty and offers hope.

No suggested reading list on the theme of women's poverty in developing societies can fail to recommend economist Ester Boserup's classic book, Woman's Role in Economic Development (London: George Allen and Unwin, 1970).

Finally, Foreign Policy's Web site www.foreignpolicy.com provides a series of links for readers seeking related online resources. 